A N NALES

UNIVERSITATIS MARIAE CURIE-SKŁODOWSKA

LUBLIN - POLONIA

VOL. XXXV

SECTIO FF

$2-2017$

\title{
RENATA RUSIN-DYBALSKA
}

Univerzita Karlova, Praha

\section{„Cesta za svobodou“v zrcadle mediální reality}

„Droga do wolności” w lustrze rzeczywistości medialnej

"The Road to Freedom" Reflected in Media Reality

V dubnu 2015 zahájila pražská kancelář Vysokého komisaře OSN pro uprchlíky spolupráci se sdružením META. Jejím cílem byla adaptace švédských metodických a výukových materiálů Hej Sverige, které vytvořila v roce 2013 organizace Friends a které byly věnovány problematice uprchlíků, národní identity, stereotypů, migrace a integrace. Projekt zaznamenal velký úspěch nejen ve Švédsku, ale získal i pozitivní hodnocení Evropské komise, což přispělo ke vzniku myšlenky využít jej i v jiných zemích. Připravené materiály měly být učitelům nápomocny př̀ realizaci obtížných, avšak aktuálních témat. Výběr partnera na české straně nebyl náhodný. Sdružení META jako nezisková organizace bojuje od roku 2004 pomocí nejrůznějších projektů o rovné př́ležitosti cizinců v oblasti vzdělávání a pomáhá jim v integraci v novém prostředí. ${ }^{1}$ Proces přizpůsobení materiálů českým reáliím probíhal $\mathrm{v}$ několika etapách. Nejprve byly materiály představeny malým skupinám učitelů. Poté byly předány dvaceti šesti učitelům ze základních a středních škol v celé zemi, kteří je testovali v práci se svými žáky. Poslední fází byl celostátní workshop uspořádaný na podzim roku 2015, kde měli učitelé mimo jiné možnost vyzkoušet si roli žáků. Všechny takto shromážděné připomínky byly zohledněny ve finální verzi didaktických materiálů, jež v listopadu 2015 získaly i kladné hodnocení ze strany českého Ministerstva školství.

20. ledna 2016 byla oficiálně zahájena kampaň Hello Czech Republic-Doma $v$ nové zemi určená žákům druhého stupně, tedy 6.-9. tříd základních škol, a stu-

\footnotetext{
${ }^{1}$ Více na téma aktivit sdružení viz www.meta-ops.cz.
} 
dentům středních škol. Připravené materiály byly veřejně prezentovány. ${ }^{2}$ Tvořily je: př́ručka pro učitele nabízející třináct metodicky zpracovaných návrhů aktivit doplněných o slovníček základních pojmů, krátký kvíz a údaje o počtech uprchlíků v Česku v letech 1990-2015, ${ }^{3}$ krátký čtrnáctiminutový film Šádí vyprávějící př́běh malé kurdské dívky ${ }^{4}$ a komiks Jednou se zase setkáme, Sanam. Př́běh o cestě za svobodou. ${ }^{5}$ Právě tento komiks se stal určitým symbolem celé kampaně, proto se mu v tomto textu budeme věnovat podrobněji.

Komiks, jehož autorem je Oskar Ekman, vypráví příběh Hamída nuceného utéct z Afghánistánu do Švédska. Poznáváme ho v roce 2012, kdy už je plnoprávným členem švédské společnosti. $Z$ této perspektivy nám vypráví svůj př́běh. Jeho první vzpomínka pochází z roku 2002, kdy spolu se svojí sestrou, titulní Sanam, a rodiči žije $\mathrm{v}$ Afghánistánu. V tuto dobu se v zemi objevují zahraniční vojáci dohlížející na pořádek a Hamídova matka, učitelka, může znovu otevřít svoji školu pro dívky. Poznáváme i dětské sny hlavního hrdiny - chce se stát leteckým mechanikem. Tato první št’astná vzpomínka, spojená s významnou soukromou událostí - narozeninami -, je ale zároveň poslední dobrou vzpomínkou. V roce 2007 se zahraniční vojáci stáhli. Vrací se Tálibové, kteří změní osud Hamídovy rodiny. Matka je nucena zavřít školu, otec se musí vydat hledat práci, i proto, aby se nemusel připojit $\mathrm{k}$ oddílům Tálibánu. Zásadním momentem se stane otcova smrt - zahyne při náletu spojeneckých vojsk. Peníze z odškodného financují Hamídův „útěk“. Ten v roce 2009 s pomocí svého strýce začíná svoji „cestu za svobodou“. Postupně se dostává do Pákistánu, Íránu (kde ho situace nutí k těžké fyzické práci), Turecka, Řecka (kde začíná poznávat život v Evropě), Itálie a Německa, odkud odcestuje do Stockholmu. Důležitou postavou, která zásadním způsobem ovlivňuje Hamídovu cestu, je Farhád, jehož poznal v Íránu. Farhád se stává nejen Hamídovým „tajným“ př́itelem, ale také zkušeným průvodcem, který mu pomůže vyhnout se pastem číhajícím na cestě. Nakonec dojde náš hrdina do cíle sám. Začátky v novém „domově“ nejsou snadné, podaří se mu však s pomocí další osoby, kterou na své cestě potká, obtíže překonat. Touto osobou je švédská sociální pracovnice Paula. S Hamídem se rozloučíme v den, kdy začíná další důležitá fáze jeho života - jde do školy.

Prezentovaný prríběh je založen na několika klíčových prvcích. Prvním z nich, zřejmým již od začátku, je pečlivé faktografické zpracování textu. Publikace vznikla na základě rozhovorů vedených na přelomu let 2012 a 2013 s dětmi a mla-

\footnotetext{
${ }^{2}$ Všechny materiály jsou již od zahájení kampaně bezplatně dostupné na internetových stránkách sdružení META: http://www.meta-ops.cz/metodicke-a-vyukove-materialy\#Hello.

${ }^{3}$ Procházková, Lucie, Titěrová, Kristýna. (2015). Hello Czech Republic-Doma v nové zemi. Př́ručka pro učitele. Praha: META, o.p.s.

${ }^{4}$ Www.youtube.com/watch?v=w6wkAUqqmag.

${ }^{5}$ Ekman, Oskar. (2015). Jednou se zase setkáme, Sanam. Př́běh o cestě za svobodou. Praha: META, o.p.s.
} 
dými lidmi, kteří sami, bez rodičů, přicestovali do Švédska. Než dojde na samotný příběh, seznámí se čtenář komiksu s ručně namalovanou mapou dokumentující jednotlivé fáze hrdinovy cesty. Výchozí bod, tedy Afghánistán, je zemí, kde pobývají cizí vojska zaručující bezpečnost a pomáhající v boji s bezohlednými Táliby. Je to také místo, kde nejsou práva žen stejná jako práva mužů, což je ukázáno zejména na př́kladu vzdělávání, ale také dětských snů. Hamídův otec připomíná jeho sestře, že ona se nemůže stát pilotem, protože je dívkou. Snaha o pečlivé zachycení reálií je patrná i z popisu organizace Hamídova útěku do Evropy. Jsme svědky vyjednávání s převaděči, dozvídáme se, kdo je hawaladar ${ }^{6}$ nebo dublin, ${ }^{7}$ i to, jak dlouho může člověk zůstat v Řecku po absolvování registrační procedury. Pozornost si zasluhuje také preciznost, s níž jsou v komiksu zachyceny detaily. Odškodnění za smrt otce činí tři tisíce dolarů, v Íránu pracuje náš hrdina deset měsíců dvanáct hodin denně (s jediným volným dnem), aby si vydělal na další fázi útěku, a v řecké ubytovně musí zaplatit pět euro za noc, pokud chce spát v pokoji pro několik osob na palandě.

Dalším podstatným prvkem př́iběhu je jeho dětský hrdina. Souvisí to samozřejmě s adresáty komiksu, jimiž by podle metodických podkladů měli být žáci alespoň 6 . tř́ídy, tedy minimálně dvanáctileté děti. ${ }^{8}$ Takový výběr hrdiny souvisí i s obrazem světa, v němž je exponován dětský pohled na věc. Jak Hamíd, tak i jeho sestra mají své sny, volný čas tráví zábavou a jsou rádi, když je doma hodně jídla. Jejich oblíbeným pokrmem je rýže s jehněčím, zeleninou, rozinkami a ořechy. Není náhodou, že je to zároveň afghánské národní jídlo. Střet tohoto selankovitého světa s politickou realitou má také svůj dětský rozměr. Od zahraničních vojáků dostává Hamíd jídlo, ale také sladkosti. „Sladký motiv“ se vrací i během jeho útěku do Evropy. Farhád, jehož Hamíd poznal v Íránu, mu jako důkaz navázaného přátelství nabízí tyčinku Snickers, která se tak stává symbolem nového, lepšího světa. „Dětským způsobem“ jsou prezentována i některá fakta. Např́íklad útok na Světové obchodní středisko, jenž je uváděn jako hlavní důvod přítomnosti cizích vojsk v Afghánistánu, popisuje hrdina následujícím způsobem: „Ř́ká se, že v Americe narazila letadla do mrakodrapư“ (Ekman, 2015:4). Přes všechny těžké okamžiky a rychlou školu dospívání, jakou Hamíd projde před našima očima, s ním jeho dětskost zůstává až do konce. Když se toulá po prázdných a cizích ulicích Stockholmu, rozhodne se přijmout pomoc náhodného taxikáře, protože je to Íránec a hovoří persky, ale i proto, že má „,velké přátelské oči“ (Ekman, 2015:51).

Dětský hrdina může i přes všechny obtíže, které ho na cestě potkají, vždy počítat s pomocí různých lidí či organizací. Zpočátku plní tuto roli samozřejmě

${ }^{6}$ Hawaladar - prostředník v arabském systému předávání peněz z ruky do ruky.

${ }^{7}$ Dublin - osoba podléhající Dublinské úmluvě, tedy smlouvě podepsané 15. 6.1990 v rámci Evropského společenství, která se týká pravidel hodnocení žádostí o azyl v členských státech Evropské unie.

${ }^{8} \mathrm{~V}$ Česku začíná povinná školní docházka v šesti letech. 
rodina, pak se postupně objevují jeho strýc z matčiny strany, který Hamídovi pomáhá při vyjednávání s převaděči, Farhád, bez jehož znalostí, protřelosti a zkušeností by se Hamídovi pravděpodobně nepodařilo dostat až do Švédska, kněz a sestry z berlínského kostela, kteří mu nabídnou nocleh a stravu, již zmíněný íránský taxikáŕ, jenž ho pohostí ve svém domě a zavede jej do uprchlického centra ve Stockholmu, nebo na závěr švédská sociální pracovnice Paula, bez jejíž pomoci by se Hamídovi nepodařilo v nové realitě zorientovat.

Zvláštní místo mají v Hamídově příběhu emoce. Ty nejsilnější jsou spojeny s rodinnými pouty. Jejich předzvěstí je scéna rozhovoru Hamída s jeho sestrou. Ta prosí svého bratra, aby ji ochránil před Táliby. Hamíd se nejprve pokouší přenést tuto odpovědnost na otce, po chvíli však sestru uklidňuje, že bude vždy stát při ní. Tento slib hrdinu doprovází během jeho útěku a stává se jeho nadějí. Sestra s ním zůstává různými způsoby - její jméno je heslem, které Hamíd uvede svému hawaladarovi, vidí ji v různých dívkách, které na své cestě potkává. Symbolická je v tomto ohledu poslední scéna, kdy se učitel ptá Hamída na rodinu. Ten odpovídá: „Měl jsem mámu a malou sestru.“ Když jej učitel opraví a říká „Máš malou sestru“, Hamíd ujišt’uje sám sebe: „To je pravda. Já mám malou sestru. A jednou se zase setkáme, Sanam“ (Ekman, 2015:57-58). ${ }^{9}$

Stejně emocionální je scéna rozloučení Hamída s otcem, jenž ho informuje, že po jeho odchodu bude právě Hamíd hlavou rodiny. Udivený a vystrašený hrdina mu odpovídá:,,Ale já jsem malý. Nejmenší z celé tř́ídy!“ (Ekman, 2015:9).

Symbolem trvalého, ale současně přerušeného kontaktu s rodinou se stávají neúspěšné pokusy o telefonní rozhovor s matkou - nejprve se Hamídovi ozve jen hlasová schránka, později číslo přestane existovat. Dalším emocionálním momentem je rozloučení s Farhádem, jenž se po únavné cestě v podvozku nákladního automobilu dostává za doprovodu policejní eskorty do vojenské nemocnice. Funkci informování o negativních emocích přejímá i obraz. Je to patrné zejména v okamžiku, kdy hrdina končí vyprávění o svém útěku. Když popisuje své dojmy poté, co se dostal do Švédska, říká: „Dny byly tmavší a tmavší. Připadal jsem si děsně prázdný. Děly se špatné věci..." (Ekman, 2015:54).

Tato slova doprovází obraz zakrvaveného umyvadla, v němž leží žiletka. Různá intenzita emocí je vyjádřena i s pomocí grafiky a barev. Jasné a živé barvy jsou pozadím pro št’astné chvíle v hrdinově životě, zatímco ty smutné doprovázejí barvy šedé, rozmyté a potemnělé.

Posledním podstatným prvkem příběhu je pak motiv související se vzděláváním. Ten je v hrdinově životě neustále přítomen díky postavě Hamídovy matkyučitelky, která nejen vede školu pro dívky, ale pomáhá se čtením a psaním všem těm, kteří tyto dovednosti neovládli. Cílem Hamídova útěku se stává Švédsko, „protože se říká, že je to nejlepší země, pokud chceš studovat““ (Ekman, 2015:35).

\footnotetext{
${ }^{9}$ Obě slovesné formy jsou navíc zvýrazněny graficky tučným fontem.
} 
První den ve švédské škole se stává první významnou fází nového života hrdiny komiksu a současně symbolickým koncem i začátkem jeho „cesty za svobodou“.

Když byla zahájena kampaň s takovouto tematikou a v takovém okamžiku, museli její autoři počítat s nejrůznějšími reakcemi. Zdá se však, že to, jak ji v zrcadle své reality zobrazila média, za vydatné pomoci předních českých politiků, překročilo i jejich nejsmělejší očekávání. V den oficiální prezentace kampaně hlásaly novinové titulky:

Žáci si budou hrát na uprchlíky ze zamořeného Česka po jaderné havárii. Kampaň zaštit’uje ministerstvo školství (Hronová, 2016).

Komiks a útěk ze zamořeného Česka. Děti se mají vžít do role uprchlíků (Trachtová, 2016).

Nová kampaň naučí děti vcítit se do role uprchlíka (Besser, 2016).

Téhož dne byla první odvysílanou zprávou v hlavním zpravodajském pořadu soukromé televize NOVA reportáž nazvaná „Svérázný komiks má mládež naučit pochopit migraci“. Její autor, Jakub Bystřický, sice v názvu naznačuje, že bude řeč o komiksu, avšak za téma svého př́spěvku si vybral jeden z návrhů aktivit nazvaný Útěk do Peacestánu, jenž je součástí prríručky pro učitele. Hlavní úkol pro žáky byl formulován takto:

Píše se rok 2030 a v České republice došlo k jaderné havárii. Země bude po příštích 200 let neobyvatelná. Deset miliónů Čechů okamžitě prchá do zahraničí. Jen jedna země světa projevuje ochotu přijmout uprchlíky z České republiky. Je to Peacestán, asijská země se 300 milióny obyvatel (Procházková a Titěrová, 2015:61).

V důsledku protestů obyvatel Peacestánu se tamější vláda rozhodne, že každý Čech, který se tam chce usadit, musí odpovědět na devět otázek. Nejprve je třeba ve třech bodech vysvětlit, co tvoří českou kulturu. Mezi dalšími otázkami je pak např́klad ta, zda si Češi v nové zemi budou chtít uchovat právo na vlastní kulturu, praktikovat své náboženství, vzdělávat se ve vlastním jazyce, mít volební právo apod. Informace o atypickém úkolu byla v televizní reportáži dokreslena výjevy atomového hřibu. Učitel, jehož redaktor poprosil o komentár̆, konstatuje: „Radio-aktivní sice není, ale i tak tato nová metodická příručka štěpí naše pedagogy na dva tábory.“ Jiný učitel dodává: „Tak fantasmagorické teze nebudu komentovat." Není těžké uhodnout, jak budou celou záležitost komentovat rodiče, kteří - jak tvrdí reportér televize NOVA - „mají branná cvičení v plynových maskách a pláštěnkách ještě v živé paměti.“ „Není to vhodný, strašit děti,“ ̌ŕká jeden z nich. Reportáž uzavírá informace o tom, že materiály byly schváleny Ministerstvem školství.

Již druhý den se téma nových didaktických materiálů objevilo v českém parlamentu. Mistryně školství Kateřina Valachová v odpovědi na poslanecké interpelace prohlásila, že její ministerstvo nemá s těmito materiály nic společného, 
nepodpořilo jejich autory finančně ani nepřevzalo patronát nad kampaní. Zároveň dodala, že nedovolí, aby byly děti takto strašeny a vtaženy do takto zásadní celospolečenské debaty. Média o této události informovala dalšími halasnými titulky vyzdvihujícími strach, ale také nejasný postoj Ministerstva školství: „Nestrašte děti. Valachová dala ruce pryč od uprchlického komiksu“ („Nestrašte děti...“, 2016). „Hru, ve které se české děti měly stát uprchlíky, ministerstvo do škol nepustí. Žáky by prý vyděsila“ (Bartoníček a Hronová, 2016).

Jako další se do debaty vložil český prezident Miloš Zeman:

Je to další idiotský projekt vysokého komisaře OSN pro uprchlíky, ty komiksy. Myslím si, že je to stejně naivní jako bolševická propaganda, která sice neměla formu komiksu, ale byla v podstatě stejně stupidní“ (,Zeman: Dětský komiks...“, 2016).

Tato slova pronesl prezident $\mathrm{v}$ jednom $\mathrm{z}$ pořadů Televize Prima. $\mathrm{V}$ tomto bodě je třeba vysvětlit, že ve věci př́stupu k uprchlíkům je česká politická scéna silně rozdělená. Toto téma se od začátku stalo horkým politickým bramborem nejen pro opozici. V čele tábora odpůrců přijímání uprchlíků do Česka stojí totiž právě hlava státu, zahajující tak svůj boj o znovuzvolení do funkce. Zeman je navíc proslulý svými ostrými a nepř́liš diplomatickými vyjádřeními. Jedním z nejznámějších jsou tzv. tři přikázání, tedy:

První věta zní: Nikdo vás sem nezval. Druhá věta: Když už tady jste, tak musíte respektovat naše pravidla, stejně jako my respektujeme pravidla, když přijedeme do vaší země. Třetí věta: Když se vám to nelíbí, běžte pryč. ${ }^{10}$

Na opačné straně politické barikády stál tehdejší český premiér Bohuslav Sobotka, který se pokoušel zmírnit ostrý tón prezidentova vyjádření: „Nebezpečí představuji teroristé, ne uprchlíci. Rizikem pro evropskou bezpečnost jsou bojovníci Islámského státu, ne ti, kteří před nimi utíkají."11

„Uprchlíci nejsou organizovaná armáda, “" ${ }^{2}$ řekl posléze v reakci na prezidentovu kritiku kampaně Hello Czech Republic.

V titulcích a v mediálních výpovědích nejrůznějších osob se nejčastěji objevovalo slovo „komiks“. Toto téma získalo dokonce status kličové události (Bronsius a Eps, 1993:512-530) vytvářející rámec pro další informování, ale především iniciující objevení se nového tématu v médiích. ${ }^{13}$ Přesto se čtenáři o komiksu

${ }^{10}$ Tato slova pronesl prezident Zeman v rozhovoru pro deník Blesk v rámci cyklu $S$ prezidentem v Lánech, cit. podle („Zeman vs. Uprchlíci...“, 2016).

${ }^{11}$ Uvedená slova premiéra Sobotky pocházejí z prohlášení vydaného dne 24. 11. 2015, cit. podle („Komentář premiéra Sobotky...“, 2016).

${ }^{12}$ Slova premiéra Sobotky cituji podle Kopecký, 2016.

${ }^{13}$ Díky kampani Hello Czech Republic se česká média začala více zajímat o možnosti využití komiksu v nejrůznějších společensko-politických kampaních. Informovala mimo jiné o komiksu, 
samotném př́liš nedozvěděli. Například v článku nazvaném Diplomatický spor o uprchlický komiks věnuje jeho autor komiksu sotva jednu větu: „Komiks dál ukazuje př́běh uprchlíka z Afghánistánu Hamída, který se vydá na nebezpečnou pout' do Švédska“ (Zelenka, 2016). Komiks se tak stal pouze záminkou pro prezentaci témat, která byla z pohledu médií výhodnější. „Nejvděčnějším“ momentem se proto stala již výše zmíněná aktivita nazvaná Útěk do Peacestánu, která - jak se později ukázalo - získala nejvíce kladných hodnocení učitelů i žáků, kteří se podíleli na testování materiálů. „Komiks, film a hra, v níž si děti měly představovat, že v Česku vypukla jaderná katastrofa a ony musí utíkat do jiné země, se do škol nakonec vůbec nedostanou“ (Bartoníček a Hronová, 2016), mohli jsme si přečíst v jednom z článků. Díky tomu byli všichni ti, kteří obsah komiksu neznali, přesvědčení, že pojednává právě o jaderném výbuchu v Česku. V některých novinách se navíc objevilo i chybné datum - výbuch byl z roku 2030 přesunut do roku 2017. ${ }^{14}$ Nejabsurdnější reakcí se stalo oficiální prohlášení největší české energetické firmy ČEZ, v němž společnost vyzvala, aby byl z materiáli̊ tento návrh aktivity odstraněn, nebot' situace $v$ něm prezentovaná je nereálná a výrazně poškozuje dobré jméno ČEZu, ,nemluvě o faktu, že je v př́mém rozporu se státní politikou snižování emisí a boje proti globálnímu oteplování. “15 Tím, že média zaměřovala svoji pozornost i pozornost svých čtenářů na jeden vybraný konspekt, př̌šla zcela mlčením fakt, že $\mathrm{v}$ příručce lze najít návrhy lekcí věnovaných problematice předsudků, odlišnosti či integrace, které se odvolávají na situace z každodenního života žáků, nebo že v ní najdeme i návrh aktivity vycházející z životního př́iběhu švédského herce Sorana Ismaila, jenž přijel do Švédska jako dítě spolu s rodiči z Kurdistánu, či pákistánské bojovnice za práva žen a držitelky Nobelovy ceny míru Malály Júsufzajové. Materiálem, o němž se média takřka nezmínila, byl film. Jediné, co se o něm mohl pozorný čtenář z médií dozvědět, byla informace, že „vypráví příběh kurdské dívky Šádí, kterou matka vyslala do Švédska“ (Trachtová, 2016). Vyzdvihováno bylo nejasné stanovisko Ministerstva školství, jež bylo o chystané kampani od začátku informováno. Jeho zástupci se účastnili jednotlivých fází adaptace původních materiálů na české podmínky, náměstek ministryně školství byl také přítomen na oficiálním zahájení kampaně. Situace se však zásadním způsobem změnila $\mathrm{v}$ okamžiku, kdy byla ministryně v parlamentu nucena veřejně se $\mathrm{k}$ tomuto tématu vyjádřit - a k údivu autorů projektu i jeho př́́znivců se od něj plně distancovala.

Takto prezentovaná kampaň, kterou komentovali i přední čeští politici, se setkala se stejně ostrou kritikou i ze strany veřejnosti:

který vznikl v Německu v souvislosti se silvestrovskými útoky imigrantů na ženy, nebo o komiksu, $\mathrm{s}$ jehož pomocí bojuje Vladimir Putin s korupcí.

${ }^{14}$ Viz např. Hronová, 2016.

${ }^{15}$ Fragment prohlášení cituji podle Titěrová, 2016. 
Opravdu nechápu, proč by se měly takové věci probírat s dětmi ve škole a motat jim hlavy. Jakou to má souvislost s uprchlíky? ${ }^{16}$

propagandistický hnus zaměřený na děti, fuj ${ }^{17}$

Oblbování našich dětí za naše peníze. ${ }^{18}$

Co je jisté, je fakt, že komiks navádí k trestné činnosti. ${ }^{19}$

Tyto reakce bohužel ukazují, že většina veřejnosti nekriticky přijala obraz událostí nabízený mediálním zrcadlem. Několik dní před zahájením kampaně Hello Czech Republic byl - pod emocionálním názvem Máme strach, ukazuje průzkum. Češi se nejvic boji terorismu či uprchlikì („Máme strach...“, 2016) publikován průzkum, z něhož vyplývá, že Češi mají největší obavy z terorismu (81 \%), mezinárodního organizovaného zločinu (66 \%) a uprchlíků (65\%). Pokud jde o uprchlíky, jedná se ve srovnání se stejným průzkumem realizovaným o rok dř́ve o takřka 100\% nárůst (v roce 2015 deklarovalo strach z uprchlíků $32 \%$ respondentů). Nejhorší reakcí však byly výhrůžky, s nimiž se setkalo sdružení META. Během pěti dní obdrželo kolem padesáti nenávistných obvinění, objevila se dokonce i hrozba likvidací. Celou věcí se zabývala policie a organizátoři kampaně se rozhodli vydat prohlášení, v němž se pokusili odpovědět na výtky a ohradili se proti manipulacím a panice vyvolané médii.

Nestává se často, aby didaktické materiály vyvolaly v Česku tak živé reakce a aby se staly předmětem takového množství komentářù, včetně těch ze strany předních politiků. Materiály z kampaně Hello Czech Republic přitom nebyly první, jaké se v Česku na podobné téma objevily. Na podzim roku 2015 vytvořila Petra Slámová, učitelka základní školy v Zákupech, vlastní pomocné materiály určené žákům prvního a druhého stupně základních škol, jež měly učitelům pomoci při zpracování tematiky uprchlíků a migrace. Tyto materiály byly prezentovány v Praze, zájem o ně projevili i zahraniční učitelé, ale nedočkaly se takové mediální prezentace. Kampan̆ Hello Czech Republic byla široce zaměřeným projektem. Je třeba zdůraznit, že materiály, jež byly $\mathrm{v}$ jejím rámci připraveny, se nezaměřovaly pouze na problematiku související s uprchlíky. Navržená témata měla za cíl vyvolat diskusi na téma kulturní identity, akceptace odlišností, adaptace na nové prostředí nebo kritického hodnocení obsahu informací zprostředkovávaných médii. Všechny tyto tematické okruhy odpovídají aktuálnímu českému rámcovému vzdělávacímu programu. Kampaň však neměla štěstí - přestože politická situace v Evropě způsobila, že tematizované okruhy nabyly na aktuálnosti, ocitla se tato kampaň v samém centru mediální, ale i politické hysterie spojené s téma-

\footnotetext{
${ }^{16}$ Citát pochází z komentáře Jany Jelínkové pod článkem (Besser, 2016).

${ }^{17}$ Citát pochází z komentáře Pepy Kouckého pod článkem (Besser, 2016), zachována původní ortografie.

${ }^{18}$ Citát pochází z komentáře Jaroslava Havrdy pod článkem (Besser, 2016).

${ }^{19}$ Citát pochází z komentáře Pavla Kuchejdy pod článkem (Čaněk, 2016), zachována původní ortografie.
} 
tem uprchlíků. Médii stvořený a zároveň jimi odrážený obraz, navíc selektivní a deformovaný, tomu byl podř́zen a byl využit v politickém boji. Zdá se nicméně, že ještě jeden návrh k diskuzi, jenž se v analyzovaných materiálech také objevil, nebyl přijat, a sice diskuse o české identitě a české kultuře. Reakce médií, ale také politiků, jež vytvářely představu uzavřeného státu citlivě vnímajícího svůj vlastní obraz, ukázaly, že podobné didaktické materiály by neměly být adresovány jen dětem. Naštěstí se našli „odvážní“ učitelé, kteří se je rozhodli ve své práci využít. Sdružení META nadále organizuje pro všechny zainteresované pedagogy bezplatná školení po celém Česku. Nic to však nemění na faktu, že je ,škoda sympatického a kvalitního projektu“ (Čaněk, 2016), jak ve svém komentáři napsal Marek Čaněk, ředitel Multikulturního centra v Praze.

\section{BIBLIOGRAFIA:}

Bartoníček, R., Hronová, M. (2016). Hru, ve které se české děti měly stát uprchliky, ministerstvo do škol nepustí. Žáky by prý vyděsila. Http://domaci.ihned.cz/c1-65118800-hru-ve-ktere-seceske-deti-mely-stat-uprchliky-ministerstvo-do-skol-nepusti-zaky-by-pry-vydesila (př́stup: 01. 06. 2016).

Besser, V. (2016). Nová kampaň nauči děti vcítit se do role uprchlikka. Http://svobodneforum.cz/ nova-kampan-nauci-deti-vcitit-se-do-role-uprchlika-2/ (př́stup: 01. 06. 2016).

Brosius, H.B., Eps, P. (1993). Verändern Schlüsselereignisse journalistische Selektionskriterien? Framing am Beispiel der Berichterstattung über Anschläge gegen Ausländer und Asylanten. Rundfunk und Fernsehen, 41, s. 512-530.

Čaněk, M. (2016). Uprchlický komiks v zajetí předsudečné mediálni kampaně. Http://denikreferendum.cz/clanek/22166-uprchlicky-komiks-v-zajeti-predsudecne-medialni-kampane (př́stup: 01. 06. 2016).

Ekman, O. (2015). Jednou se zase setkáme, Sanam. Př́běh o cestě za svobodou. Praha: META, o.p.s. Hronová, M. (2016). Žáci si budou hrát na uprchliky ze zamořeného Česka po jaderné havárii. Kampan̆ zaštituje ministerstvo školství. Http://archiv.ihned.cz/c1-65109690-zaci-si-budouhrat-na-uprchliky-ze-zamoreneho-ceska (přístup: 01. 06. 2016).

Komentár premiéra Sobotky: Nebezpečí predstavuji teroristé, ne uprchlíci. Http://www.vlada.cz/cz/ clenove-vlady/premier/komentare/komentar-premiera-sobotky-nebezpeci-predstavuji-teroriste--ne-uprchlici--137397/ (př́stup: 01. 06. 2016).

Kopecký, J. (2016). Uprchlíci nejsou armáda, na uzavřeni hranic jsme připraveni. Http://zpravy. idnes.cz/sobotka-uprchlici-nejsou-armada-na-uzavreni-hranic-jsme-pripraveni-1pz-/domaci. aspx?c=A160121_104214_domaci_kop (př́stup: 01. 06. 2016).

Máme strach, ukazuje pri̊zkum. Češi se nejvíc boji terorismu či uprchliků. (2016). Http://zpravy. idnes.cz/pruzkum-cvvm-bezpecnostni-rizika-dru-/domaci.aspx?c=A160111_124212_domaci_ane (př́stup: 01. 06.2016).

Nestrašte děti. Valachová dala ruce pryč od uprchlického komiksu. (2016). Http://zpravy.idnes.cz/ vzdelavaci-program-na-podporu-uprchliku-neni-v-nasi-rezii-rika-valachova-1qm-/domaci. aspx?c=A160121_221247_domaci_rych (př́stup: 01. 06. 2016).

Procházková, L., Titěrová, K. (2015). Hello Czech Republic-Doma v nové zemi. Př́ručka pro učitele. Praha: META, o.p.s. 
Titěrová, K. (2016). Hello Czech Republic - Doma v nové zemi. Http://www.eduin.cz/clanky/kristyna-titerova-hello-czech-republic-doma-v-nove-zemi/ (př́istup: 01. 06. 2016).

Trachtová, Z. Komiks a útěk ze zamořeného Česka. Děti se maji vžit do role uprchlíků. Http://zpravy. idnes.cz/kampan-hello-czech-republic-dft-/domaci.aspx?c=A160119_143015_domaci_zt (př́stup: 01. 06. 2016).

www.meta-ops.cz

www.meta-ops.cz/metodicke-a-vyukove-materialy\#Hello

www.youtube.com/watch?v=w6wkAUqqmag

Zelenka, J. (2016). Diplomatický spor o uprchlický komiks. Komisař OSN předal výhrůžky policii. Http://www.lidovky.cz/diplomaticky-spor-o-uprchlicky-komiks-komisar-osn-predl-vyhruzkypolicii-1th-/zpravy-domov.aspx?c=A160201_134935_ln_domov_jzl 9(přístup: 01. 06. 2016).

Zeman: Dětský komiks o uprchlícich je idiotský a nebezpečný projekt. Http://www.lidovky.cz/ zeman-vzdelavaci-projekt-o-uprchlicich-je-idiotsky-a-nebezpecny-p8z-/zpravy-domov. aspx?c=A160124_113649_ln_domov_mct (př́stup: 01.06. 2016).

Zeman vs. uprchlíci a islám: Jakými slovy už je prezident počastoval? Http://www.blesk.cz/clanek/ zpravy-uprchlicka-krize/349637/zeman-vs-uprchlici-a-islam-jakymi-slovy-uz-je-prezidentpocastoval.html (prístup: 01. 06. 2016).

\section{STRESZCZENIE}

Tematem atrykułu jest medialny obraz kamapnii Hello Czech Republic, zorganizowanej w Czechach w roku 2016 przez stowarzyszenie Meta. Jej zadaniem była adaptacja do czeskich warunków szwedzkich materiałów dydaktycznych związanych z uchodźcami, tożsamością narodową, stereotypami czy migracją, które miały pomóc w pracy czeskim nauczycielom. Składały się na nie: podręcznik dla nauczycieli z propozycjami trzynastu lekcji, film Šádi prezentujący historię kurdyjskiej dziewczynki oraz komiks Jednou se zase setkáme, Sanam. Př́běh o cestě za svobodou, opowiadający historię Hamida, zmuszonego do ucieczki z Afganistanu do Szwecji. Szczegółowo prezentowany w artykule komiks został głównym bohaterem doniesień medialnych. Odbiorcy nie mogli jednak dowiedzieć się na jego temat zbyt wiele, gdyż stał się jedynie pretekstem do prezentacji treści korzystniejszych z punktu widzenia mediów. Motywem przewodnim większości informacji stało się zdanie opowiadające o fikcyjnej awarii jądrowej w Czechach, które podniosło falę krytyki skierowaną pod adresem kampanii ze strony nie tylko mediów, ale również najbardziej wpływowych polityków w Czechach. Stworzony przez media wybiórczy i zniekształcony obraz został w ten sposób podporządkowany aktualnym wydarzeniom w kraju i wykorzystany w walce politycznej.

Słowa klucze: medialny obraz, Hello Czech Republic, materiały dydaktyczne, uchodźcy

\section{SUMMARY}

The goal of this paper is to present the media image of campaign "Hello Czech Republic", organized in the Czech Republic in 2016 by the Meta association. Its task was to adapt to the Czech conditions Swedish teaching materials on refugees, national identity, stereotypes or migration, which would help in the work of Czech teachers. They consisted of a manual for teachers with suggestions of thirteen lessons, film Šádí, presenting the story of a small Kurdish girl, and comic book Jednou se zase setkáme, Sanam. Přiběh o cestè za svobodou, telling the story of Hamid, who was forced to escape from Afghanistan to Sweden. The comic book, which was presented in the article in more detail, became the main subject of media reports. However, the recipient is not able to find 
out about it too much because it has become only a pretext for presenting the content more favorable from the point of view of the media. Therefore, the main theme in most of the media information has become one of the tasks, telling of a fictional nuclear accident in the Czech Republic, which effectively raised a wave of criticism directed at the campaign, not only from the media, but also the most important politicians in the Czech Republic. Selective and distorted image, created by media, was thus subordinated to current events in the country and used in the political struggle.

Keywords: media image, "Hello Czech Republic", educational materials, refugees

\section{SHRNUTÍ}

Tématem textu je mediální obraz kampaně Hello Czech Republic, kterou v Česku v roce 2016 zorganizovalo sdružení Meta. Jejím cílem byla adaptace švédských didaktických materiálů věnovaných problematice uprchlíků, národní identity, stereotypů či migrace na české poměry. Tyto materiály měly pomoci v práci českým učitelům. Tvořily je př́ručka pro učitele s návrhy třinácti aktivit, film Šádí zachycující osudy malého kurdského děvčátka a komiks Jednou se zase setkáme, Sanam. Př̉běh o cestě za svobodou, jenž vypráví př́iběh Hamída nuceného utéct z Afghánistánu do Švédska. Právě tento komiks, jemuž bude v textu věnována větší pozornost, se stal zdánlivým hlavním hrdinou mediálních sdělení. Lidé se však o něm př́liš nedozvěděli, nebot' se ve skutečnosti stal pouze záminkou $\mathrm{k}$ představení mediálně vděčnějších témat. Vůdčím tématem většiny mediálních sdělení se proto stala jedna z aktivit pojednávající o fiktivní jaderné havárii. Právě to spustilo na celou kampaň vlnu kritiky, a to nejen ze strany médií, ale také nejvýznamnějších českých politiků. Selektivní a nepřesný mediální obraz této kampaně tak byl podřizen aktuálním problémům, které Česko v té době řešilo, a byl využit $\mathrm{v}$ politickém boji.

Klíčová slova: mediální obraz, Hello Czech Republic, výukové materiály, uprchlíci 